\title{
Handling Florida Vegetables Series - Round and Roma Tomato Types ${ }^{1}$
}

\section{Steven A. Sargent, Jeffrey K. Brecht and Teresa Olczyk ${ }^{2}$}

In 2003, total U.S. commercial production of fresh-market tomatoes was over 1.6 million tons, of which Florida produced about $43 \%$ and California about $28 \%$. About 43,000 acres of tomatoes were harvested in Florida during the 2002 - 2003 growing season. This can be divided into fall and spring/summer crops with about 13,000 acres planted between August and December and the remaining 30,000 acres planted between January and July. Main tomato growing areas include: Miami-Dade County, Southwest Florida and Palm Beach-Fort Pierce regions, Tampa Bay area and Florida's Panhandle area west of Tallahassee. Of the $\$ 1.41$ billion total farm value of vegetables produced in Florida, tomatoes accounted for about $40 \%$, or $\$ 547$ million. Florida also produces a significant amount of roma, grape and cherry tomato types and a smaller amount of greenhouse-grown tomatoes. U.S. tomato imports come primarily from Mexico, which exported slightly more than California's annual production. Other imports are from Canada, Holland, and Spain, and are primarily grown under protected culture.
Upon completion of growth on the plant, tomato fruit can be harvested green and ripened off the plant. Many commercial tomato growers employ this green-harvest system to extend the marketing period. After packing, the green tomatoes are placed in specially constructed rooms and exposed to the natural ripening hormone ethylene to initiate and coordinate ripening. If picked at the proper mature-green stage and handled properly, tomatoes will ripen to excellent edible quality. Proper postharvest handling of Florida tomatoes is critical to ensure the continued competitiveness of Florida growers.

This publication will focus on round and roma (plum) tomatoes since these types are handled similarly under commercial conditions.

\section{Obtaining Quality}

Nutritional Value -Tomatoes rank first in the "relative contribution to human nutrition" when compared to 39 major fruits and vegetables (See Reference 8)

1. This document is SS-VEC-928, one of a series of the Horticultural Sciences Department, Florida Cooperative Extension Service, Institute of Food and Agricultural Sciences, University of Florida. Original publication date August 1, 1989. Revised November 3, 2005. Reviewed November 3, 2005. Visit the EDIS Web Site at http://edis.ifas.ufl.edu.

2. Steven A. Sargent, Professor, Horticultural Sciences Department; Jeffrey K. Brecht, Professor, Horticultural Sciences Department; Teresa Olczyk, Extension Agent III, Miami-Dade County Extension. Cooperative Extension Service, Institute of Food and Agricultural Sciences, University of Florida, Gainesville, 32611.

The Institute of Food and Agricultural Sciences (IFAS) is an Equal Opportunity Institution authorized to provide research, educational information and other services only to individuals and institutions that function with non-discrimination with respect to race, creed, color, religion, age, disability, sex, sexual orientation, marital status, national origin, political opinions or affiliations. U.S. Department of Agriculture, Cooperative Extension Service, University of Florida, IFAS, Florida A. \& M. University Cooperative Extension Program, and Boards of County Commissioners Cooperating. Larry Arrington, Dean 
One medium sized tomato provides $40 \%$ of the Recomended Daily Allowance (RDA) of vitamin C (ascorbic acid), 20\% of the RDA of vitamin A, substantial amounts of potassium, dietary fiber, calcium, and lesser amounts of iron, magnesium, thiamine, riboflavin, and niacin, yet contains only about 35 calories. Tomatoes are particularly rich in lycopene (the red pigment in tomato fruit), vitamin $\mathrm{C}$, and a variety of other natural antioxidants, which have been associated with decreased risk of chronic diseases such as cancer and cardiovascular disease. Based on nutrient content and the quantity of tomatoes consumed, they are major contributors to our health.

Cultivar Selection - Cultivar selection is one of the most important management decisions in successful tomato production. Due to its geographic location, Florida has numerous microclimates and growing seasons. Suitable cultivars should have the following characteristics: economic yield, resistance to pests and adaptability to local soil and climatic conditions. Horticultural quality of fruit and acceptance by markets are other important cultivar qualities. Recommended round-type tomato cultivars for Florida include: 'Amelia', 'BHN-640', 'Florida 47', 'Florida 91', 'HA 3073', 'Sanibel', 'Sebring', 'Solar Fire', 'Solar Set', 'Solimar' and 'Tygress'. Recommended roma-type cultivars include 'Plum Dandy', 'Spectrum 882' and 'Supra'.

Cultural Practices - Cultural practices necessary for production of quality marketable yields include: field preparation (multiple disking, laser leveling and digging of irrigation ditches in some production areas), fumigation and bed preparation (bed shaping, pre-plant fertilizer application, methyl bromide or suitable approved alternative application, laying of drip tubes and plastic mulch), setting tomato transplants in the field, irrigation and nutrient management, pruning, staking and tying of tomato plants, scouting and application of pesticides, harvesting, and destruction of the crop after last harvest. Suitable wind breaks are needed in some production areas to protect young plants and reduce sand scarring of tomato fruits. Optimization of irrigation and nutrient management is a key practice leading to optimum plant growth and high yields and preventing ground water pollution. Actual practices vary depending upon location and irrigation system.

\section{Harvest and Transport Operations - Fresh} market tomatoes are hand-harvested in Florida (Fig. 1). The harvest crew needs to be trained and supervised so that immature, over mature, defective, and decayed tomatoes are left in the field. This reduces the need for subsequent grading and minimizes the chances of spreading decay to sound tomatoes during handling and shipping. Plants should also be dry prior to harvest to reduce spread of decay pathogens in the field.

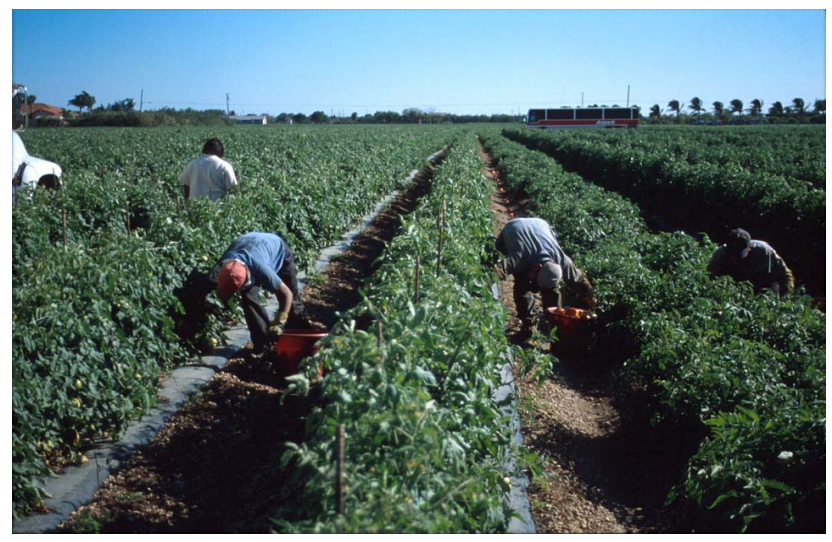

Figure 1. Hand harvest allows for multiple pickings. Credits: (J.K. Brecht)

For green-harvest operations, harvest maturity is critical to ensure proper ripening and flavor. External indicators of tomato maturity are: position on the plant (fruit set occurs from the bottom up), size, shape, surface appearance (waxy gloss or sheen), and the presence of brown corky tissue on the stem scar. External indicators are not completely reliable; therefore, prior to harvest tomato samples should be taken throughout the field, sliced, and rated for internal indicators. Internal indicators are rated on a scale of M1 to M4 based on locule gel and seed coat development (Table 1 and Fig. 2). These maturity ratings apply to both round and roma types.

Tomato fruit ripening begins internally as described by the M1 through M4 maturity ratings, and continues as red color develops on the surface of the fruit. Green tomatoes picked at M3 and M4 stages will ripen to the best eating quality; those picked at M2 will ripen with quality suitable for food service, and those picked at M1 will never ripen properly. It is not uncommon to find $20 \%$ or more of a harvested lot 


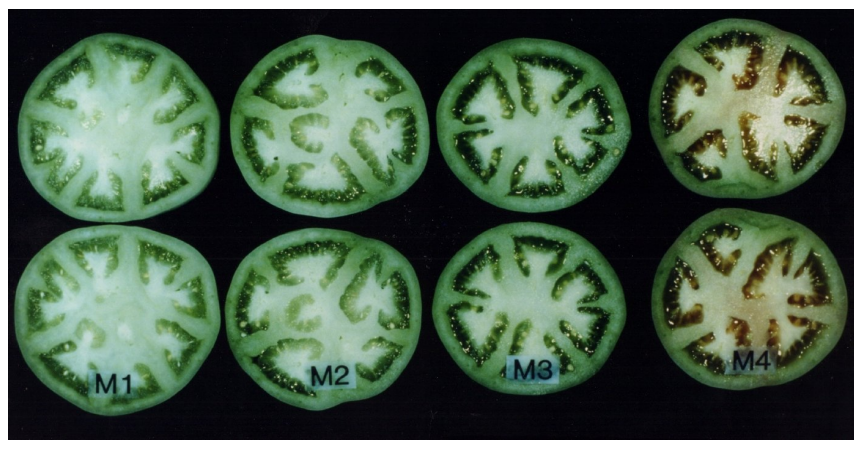

Figure 2. Internal appearance of tomatoes according to maturity ratings $\mathrm{M} 1$ to M4. Credits: (J.K. Brecht)

of green tomatoes to be at M1 stage. The first appearance of red color on the fruit surface is called the 'breaker' stage, and color development continues through 'turning,' 'pink,' 'light red' and 'red' stages (Table 2). Tomatoes harvested at any color stage from breaker on are collectively referred to as "vine ripe." The advantage to harvest at breaker stage is that all tomatoes will ripen normally; however harvest constraints such as labor availability and price may limit the ability of growers to harvest at this stage.

Green-harvested tomatoes are picked into plastic buckets, which are emptied into field (pallet) bins on flat-bed trucks or into gondolas (Fig. 3). A pallet bin holds about 1,000 pounds of fruit and a gondola from 8 to 12 tons. The bins or gondolas should be positioned in the field near the harvest crew to minimize the walking distance. Tomatoes are sensitive to mechanical damage during harvest and handling. Therefore, the harvest crew must be trained and supervised to ensure gentle handling at harvest and when transferring into the bins and gondolas. Drop heights should be kept to a minimum to reduce bruising. To avoid crushing, field bins should not be overfilled. Round and roma tomatoes picked at breaker stage or later may be picked directly into lugs and stacked on pallets in the field. Dirty buckets, bins and gondolas should be cleaned to reduce decay cross-contamination, and those with rough surfaces, which can cause abrasion injuries, should be replaced. Containers and bins constructed from plastic can be readily cleaned and sanitized.

Although not currently used in Florida, the over-the-row conveyor harvest system shows promise in making the tomato harvest operation more

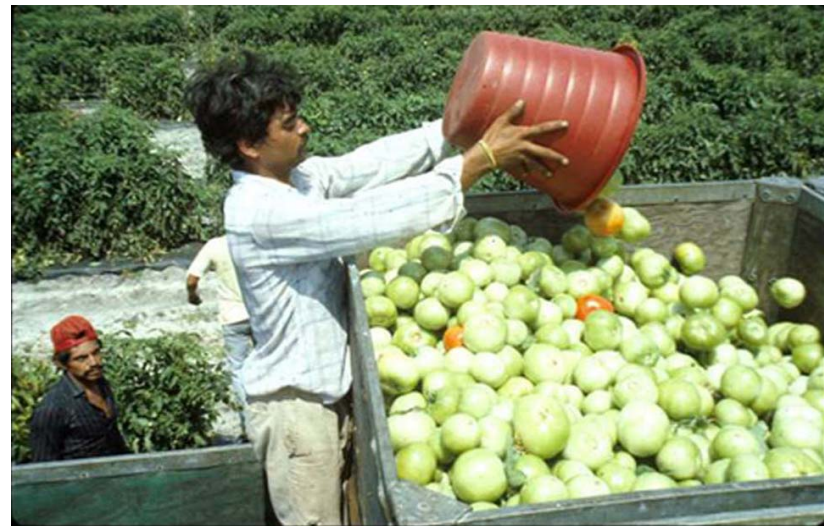

Figure 3. Field buckets must be carefully emptied to avoid bruising. Credits: (S.A. Sargent)

efficient (Fig. 4). In this system, the harvest crew still picks into buckets, but while walking behind the self-propelled conveyor. The buckets are emptied onto the conveyor, eliminating the need for the picker to walk to a distant truck or gondola. The conveyor moves the tomatoes to one side of the field, where undersize tomatoes are removed and some presorting can be done on a small packing line. The tomatoes are then transferred to an accompanying transport vehicle for hauling to the packinghouse. Our preliminary studies have shown there is potential for reducing harvest time and for removal of a significant amount of cull tomatoes in the field using the over-the-row conveyor system. These efficiencies may make this harvest operation sufficiently cost effective to permit harvesting breaker stage fruit.

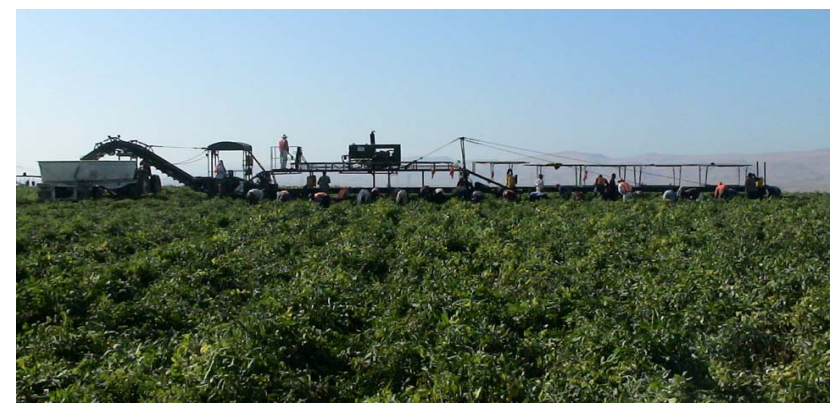

Figure 4. A mobile conveyance system makes hand harvest more efficient. Credits: (S.A. Sargent)

\section{Maintain Quality}

Unloading Operations - Upon arrival at the packinghouse, tomatoes should be processed as soon as possible. If delays occur, field bins or gondolas should be kept in the shade prior to unloading; tomatoes left in the sun for an hour can be $25^{\circ} \mathrm{F}$ hotter than those held in the shade and can become 
sunburned. Also, pulp temperatures above $85^{\circ} \mathrm{F}$ for extended periods can cause poor ripening and flavor.

Tomatoes are normally transferred into a water flume system (dump tank) for gentle transfer to the packing line. Tomatoes handled in field bins are automatically dumped into the dump tank (Fig. 5), while those in gondolas are flumed out using the dump tank water (Fig. 6). Plant pathogens will accumulate in dump tank water since the water is recirculated throughout the packing day. Therefore, dump tank water must be constantly sanitized to minimize the possibility of cross-contamination via infiltration of water and pathogenic microorganisms through the stem scar, the blossom-end scar or through cuts and punctures. If the time in the dump tank water is less than 30 seconds, water may be left at ambient temperature, however, longer exposure times require heating the dump tank water to about $10^{\circ} \mathrm{F}$ above the incoming fruit pulp temperature in order to avoid infiltration of bacterial pathogens into the tomatoes. For more details concerning management of tomato dump tanks, see Ritenour et al. (2002) and Mahovic et al. (2004).

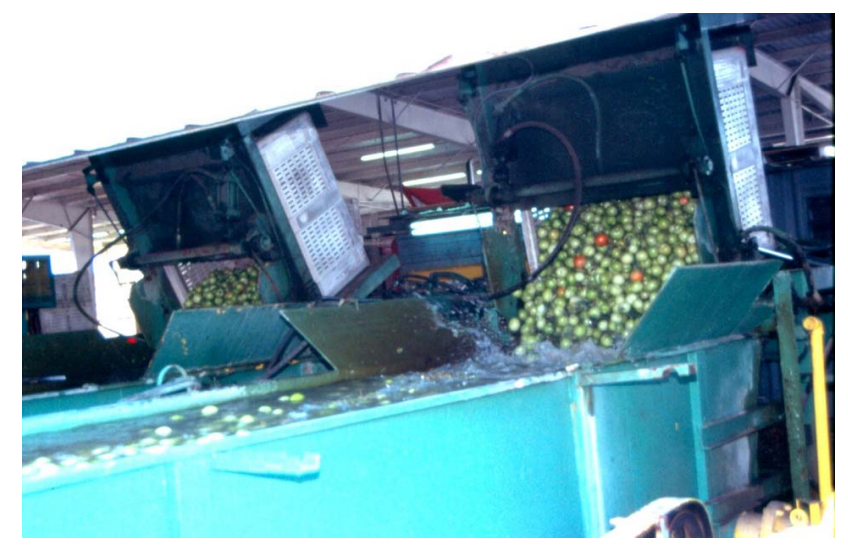

Figure 5. Transfer into a dump tank is commonly used to minimize mechanical injuries. Shown here is transfer from field (pallet) bins into dump tanks. Credits: (J.K. Brecht)

The rate at which dumping occurs is important because it determines the flow of tomatoes through the packing line. The dump rate needs to be adjusted to accommodate the degree of sorting and grading that each lot of tomatoes requires so that the packing line workers can most effectively accomplish their tasks. Studies have shown that if the packing line volume is too high, workers cannot remove all off-grade product, and if the volume is too low, they tend to remove in-grade product to keep busy.

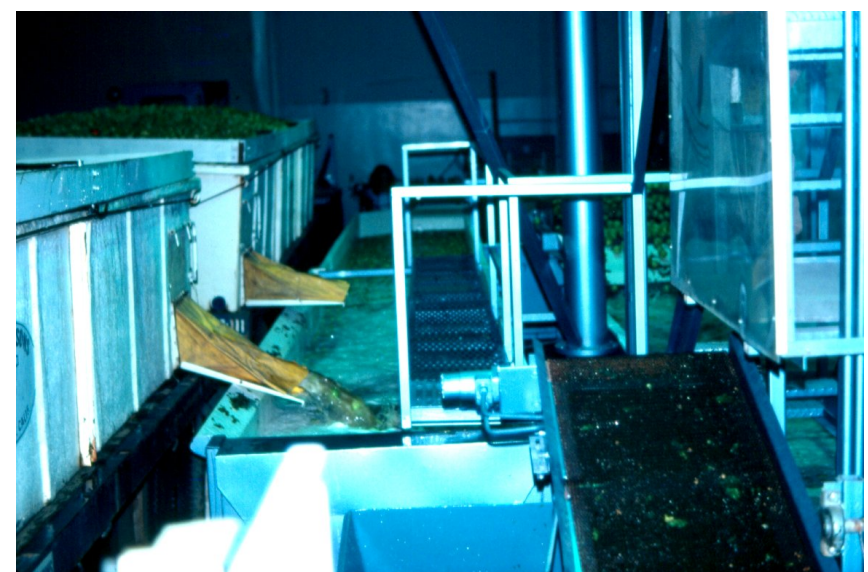

Figure 6. Tomatoes are transferred from gondolas by pumping dump tank water into the gondola and fluming them out through a chute into the dump tank. Credits: (J.K. Brecht)

After the tomatoes are elevated from the dump tank, they are brushed and rinsed, dried, sorted and graded (Fig. 7); they may or may not be waxed. Tomatoes at breaker stage or riper ('pinks') are sorted out and handled on a separate packing line. During all operations from harvesting through packing, tomatoes must be handled carefully to avoid bruising, cuts, and punctures. These injuries can interfere with ripening and promote postharvest decay during gassing, handling, and shipping operations.

Grade and Size - In Florida, green tomatoes packed in the areas regulated by the Florida Tomato Committee are graded as 'U.S. No. 1', '85\% U.S. No. 1', 'U.S. Combination', and 'U.S. No. 2' according to the U.S. Standards for Grades of Fresh Tomatoes, as modified by the Florida Tomato Committee under authority of the Federal Marketing Order (FTC, 2004).

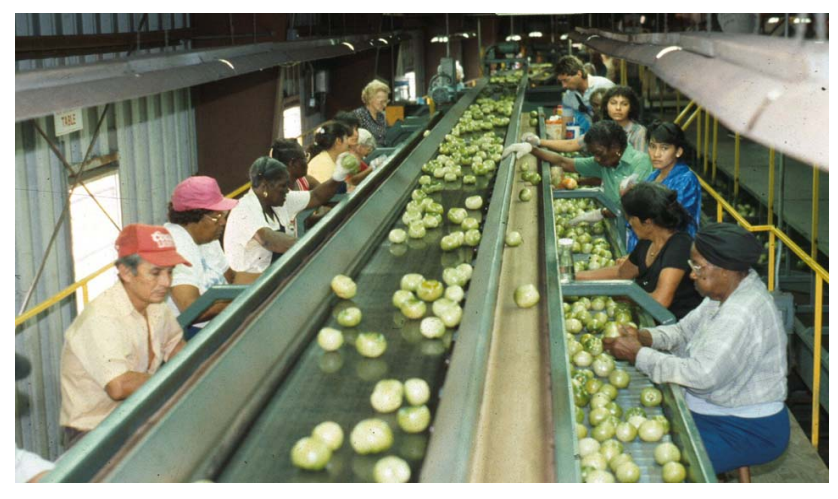

Figure 7. Grading operations are very labor-intensive and critical to quality control. Credits: (S.A. Sargent) 
Size classifications are also established by the Florida Tomato Committee and differ slightly from those specified in the U.S. Grade Standards. Although the current U.S. Department of Agriculture size classifications are 'small,' 'medium,' 'large,' etc., Florida uses the numeric classifications of ' $6 \times 7$,' '6x6,' and '5x6 and Larger.' The Florida classifications and dimensions are listed in Table 3.

Tomatoes are mechanically sized by dimensional sizers in which the fruit pass over a series of perforated belts with openings that correspond to the maximum allowable diameter for the particular size. The undersize tomatoes drop through the first sizing belt, followed by the '6x7,' '6x6,' and '5x6 and Larger' sizing belts. Electronic sizers are also available that size individual fruit optically or by weight; these systems are more often used in tomato repack or vine-ripe operations.

Pack - Sized and graded green tomatoes are jumble-packed into unwaxed, fiberboard cartons (2-piece) to a net weight of 25 pounds (Fig. 8). 'Pink' tomatoes can be packed into the same cartons or into smaller, 2-layer or single-layer cartons. Filled cartons are automatically lidded and stamped with size and grower designation. At this point tomatoes packed in the areas regulated by the Federal Marketing Order are inspected (Fig. 9).

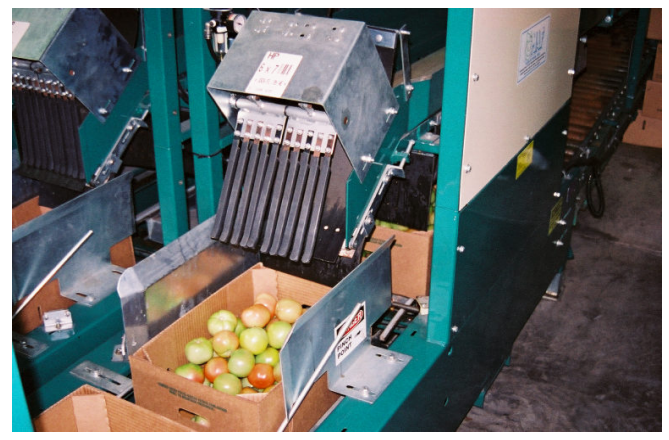

Figure 8. Shipping cartons are automatically filled by weight. Credits: (J.K. Brecht)

Prior to unitizing (stacking) on a standard pallet (40 inches x 48 inches; 100 x $120 \mathrm{~cm}$ ), a few drops of glue are placed on each lid to stabilize the stacked containers; strapping material can also be used in place of glue. Each pallet contains 80, 25-lb cartons of tomatoes (10 cartons per layer and 8 layers per pallet). Tomatoes are subsequently handled and

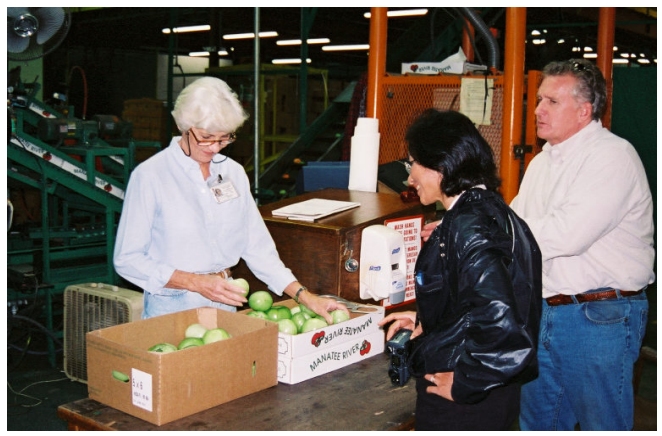

Figure 9. Federal/state inspectors conduct continuous sampling to certify that quality standards are consistent. Credits: (J.K. Brecht)

shipped as a unitized load, reducing the risk of mechanical injuries.

Ripening - Ethylene, a natural ripening hormone that is normally produced by the tomato, is used to promote faster and more uniform ripening of mature-green tomatoes. All major tomato packers and repackers are equipped with facilities for ripening initiation with ethylene gas. Many of the ripening rooms have a capacity of 40 pallets (two trailer loads) with large packers having as many as $\mathbf{5 0}$ such rooms. Other ripening rooms have capacities over 100 pallets. Ripening rooms should have precise atmospheric controls to maintain optimum ripening initiation conditions ( 68 to $72^{\circ} \mathrm{F}, 85$ to $95 \%$ relative humidity, and $150 \mathrm{ppm}$ ethylene). Adequate refrigeration capacity (to remove field heat), and air circulation (20 to $40 \mathrm{cfm}$ [cubic feet per minute] per ton of product) are required for good temperature management in the ripening room. The ripening room air must also be exchanged or ventilated on a regular basis to prevent accumulation of carbon dioxide $\left(\mathrm{CO}_{2}\right)$ by the respiring tomatoes: $\mathrm{CO}_{2}$ concentrations above $1 \%$ can retard or inhibit the initiation of ripening. If ethylene is applied in a single shot, the ripening room should be opened and ventilated for about a half-hour every 12 hours. If ethylene is applied continuously, the system should allow for one air change every 6 hours. Mature-green tomatoes typically require 24 to 72 hours of exposure to ethylene, depending on maturity, to reach the breaker stage; immature fruit (i.e., those requiring more than 5 days of ethylene treatment to reach breaker stage) are likely to never achieve full red-color and flavor. By treating tomatoes with ethylene before packing, immature fruit and fruit with decay can be sorted out before shipping, making the quality more uniform. 
Temperature management - Normal ripening of tomatoes is adversely affected by exposure to temperature extremes. Tomatoes ripen best at temperatures between $55^{\circ} \mathrm{F}$ and $77^{\circ} \mathrm{F}$. Higher temperatures (especially greater than $85^{\circ} \mathrm{F}$ ) inhibit red color development and fruit will be softer. Optimum development of red color occurs at 68 to $72^{\circ} \mathrm{F}$; ripening below $55^{\circ} \mathrm{F}$ results in slower color development, while ripening above $77^{\circ} \mathrm{F}$ results in more orange fruit.

The tomato is of subtropical origin and as such exposure to temperatures below $55^{\circ} \mathrm{F}$ will cause chilling injury. Symptoms of chilling injury, in order of appearence, are poor flavor development, impaired or abnormal color development, water-soaked spots, pitting, tissue collapse and decay (Fig. 10). Green and ripening tomatoes are more susceptible to chilling injury than ripe tomatoes. The lower the temperature to which tomatoes are exposed, the faster and more severe is the chilling injury development.

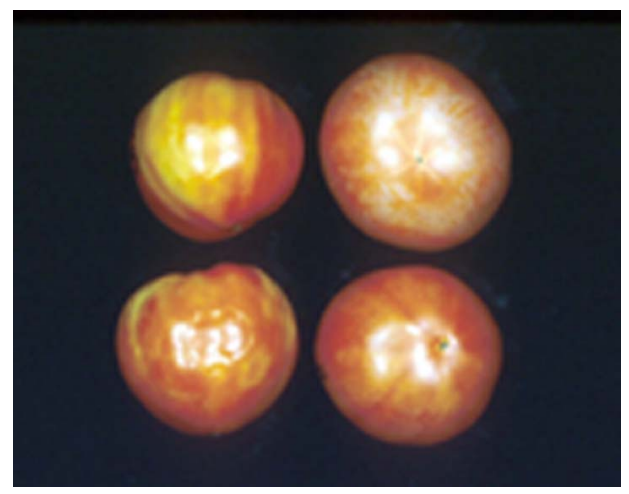

Figure 10. Storage below $55^{\circ} \mathrm{F}$ can impair normal color development during ripening. Credits: (J.K. Brecht)

Optimum ripening and holding conditions for tomatoes are 68 to $72^{\circ} \mathrm{F}$ and high relative humidity (85 to 95\%). Shelf life can be extended and quality retained if tomatoes are first ripened under the optimum conditions and then held at a reduced temperature of $55^{\circ} \mathrm{F}$. Storage at temperatures below $50^{\circ} \mathrm{F}$, both in the marketplace and in the home, is a major contributor to poor tomato quality.

Tomatoes are susceptible to water loss, mainly through the stem scar. Shriveling symptoms may become evident with as little as 3\% weight loss; storage in a high relative humidity ( 85 to $95 \%$ ) will minimize this weight loss. Tomatoes can be waxed, but only a thin coating should be applied. Waxing provides some surface lubrication, which reduces chafing during handling and transit. Care should be taken to prevent heavy waxing of the stem scar because the wax can block gas exchange and interfere with ripening.

Mixed Load/Storage Compatibility - Tomatoes have storage requirements similar to those of several other climacteric (i.e., ethylene-producing) fruits such as cantaloupe, avocado, mango and papaya; they are also compatible with winter squash and pumpkin. Therefore, these products can be transported and stored together without deleterious effects. A number of ethylene-sensitive commodities, including cucumber, eggplant, watermelon, okra, early potato, summer squash, and sweetpotato, have temperature requirements similar to those of tomatoes, but because of their sensitivity to ethylene, these commodities should never be transported or stored with tomatoes. Ice should never be placed in contact with these commodities.

Postharvest Decay and Disorders - Tomatoes are subject to several market diseases and disorders. Proper handling, grading, and temperature management will minimize the occurrence of these potentially devastating problems. Listed below are some that may occur.

a) alternaria rot - This disease may follow blossom-end rot (see below), physical injuries, chilling injury, and other decays. Large, greenish-brown to black lesions covered with grayish-brown mold are produced. The larger lesions may show alternating light-brown and dark-brown/black concentric zones.

b) bacterial soft rot - Decay may occur at injuries anywhere over the surface of the fruit. The causal organism can also be taken up through the stem scar or blossom scar of tomatoes in unheated dump tanks. Bacterial soft rot is easily recognized by the soft, mushy consistency of the affected tissues, and is generally associated with a bad odor.

c) bacterial spot and speck - Spots are small, brown-to-black, scab-like lesions that constitute blemishes of serious consequence only when they are present in large numbers 
on the fruit. Tomato cultivars show variation in susceptibility. Care should be exercised to grade out all tomatoes showing spots that would reduce their marketability.

d) blossom-end rot - This disorder frequently occurs under conditions of calcium deficiency. It disfigures the fruit and opens the way for secondary bacterial and fungal invaders that cause extensive decay. A small, water-soaked spot on the lower half of the fruit near the blossom end is the first symptom of this disorder. As the spot enlarges, it becomes light brown to brownish black and dry, so that the affected tissues are more or less leathery in texture.

e) sour or watery rot - On green fruit, watery rot lesions have a dull, greasy, and water-soaked to bleached appearance. Although the decay may originate at cracks, cuts, or skin punctures, it frequently is found starting at the edge of the stem scar. The affected tissues remain fairly firm until the decay is quite advanced and have a pickled appearance and a definite sour odor. Bacterial soft rot often follows watery rot.

f) rhizopus rot - This soft rot disease is distinguished from bacterial soft rot by the presence of coarse mold that can be seen by gently pulling apart the diseased tissue. Under humid conditions the mold may grow out over the lesions.

g) virus mottling - Stunting, distortion, yellow and green mottling, and definite rings or loops on the fruit are the usual characteristics of this disease.

h) irregular ripening - This disorder differs from blotchy ripening, which is typically a chilling injury symptom, by its streaky appearance. Irregular areas on the fruit fail to ripen and generally the affected tissue appears to be more leathery or tough. This disorder is avoided by maintaining adequate control of sweetpotato whitefly during production.
Color images of postharvest diseases, disorders and control strategies are available in the references by Mahovic et al. and Olson listed below.

Food Safety Issues - Tomatoes have been linked to several food poisoning outbreaks in recent years. Thus, setting up and maintaining an appropriate sanitation program throughout handling is important. Human pathogens can be transmitted by direct contact (infected employees or animals) or through contaminated water or soil. Once a tomato is infested, pathogens are difficult or impossible to remove. Only thorough cooking (or other similar thermal treatment, such as pasteurization) will reliably neutralize human pathogens in tomatoes. Therefore, in order to minimize the likelihood of contamination of fresh-market tomatoes by human pathogens, it is necessary to ensure that animals are excluded from tomato handling areas, that employees practice good hygiene, and that tomato handling areas and equipment are regularly cleaned and sanitized. Tomatoes that are field-packed without washing have a higher likelihood of reaching consumers with field contamination. Harvest crews for field packing must be trained especially well to avoid suspect tomatoes or practices. An extra benefit of good sanitation to growers and shippers is that sanitation also reduces infection by plant pathogens and reduces decay during shipping and storage. Keeping records of good sanitation practices is important to document adherence to a food safety plan and to help identify potential problem areas.

See references 9 and 12 below for more information on food safety for fresh produce.

\section{References}

Additional information about tomato is contained in the following publications:

1. Cantwell, M.I. and R.F. Kasmire. 2002. Postharvest Handling Systems: Fruit Vegetables. In, Postharvest Technology of Horticultural Crops. A.A. Kader (Ed.). Publ. 3311. Univ. Calif. Div. Agric. Natural Resources, Berkeley.

2. Florida Tomato Committee. 2004. Handling Regulations. Regulatory Bulletin No. 1. Sept. 2004. http://www.floridatomatoes.org. 
3. Gross, K.C., C.Y. Wang and M. Saltveit (Eds.). 2004. The Commercial Storage of Fruits, Vegetables, and Florist and Nursery Stock. USDA, ARS, Agricultural Hdbk. 66. Washington DC. http://www.ba.ars.usda.gov/hb66/.

4. Mahovic, M.J., S.A. Sargent, and J.A. Bartz. 2004. Identifying and Controlling Postharvest Tomato Diseases in Florida. Publ. HS866. Horticultural Sciences Department, Florida Cooperative Extension Service, University of Florida/IFAS, Gainesville. http://edis.ifas.ufl.edu/HS131.

5. Olsen S.M. and Simonne E.(eds). 2004. Vegetable Production Handbook for Florida 2004-2005.UF IFAS Extension and Citrus and Vegetable Magazine, Vance Publishing, Lenexa, KS.

6. Olson, S.M. 2004. Physiological, nutritional, and other disorders of tomato fruit. HS-954 Horticultural Sciences Dept., Florida Cooperative Extension Service, University of Florida/IFAS. Gainesville. http://edis.ifas.ufl.edu/HS200

7. Ritenour, M.A., S.A. Sargent, and J.A. Bartz. 2002. Chlorine Use in Produce Packing Lines. Publ. HS-761. Horticultural Sciences Department, Florida Cooperative Extension Service, University of Florida/IFAS, Gainesville. http://edis.ifas.ufl.edu/CH160

8. Saltveit, M.E. 2003. Mature Fruit Vegetables. In, Postharvest Physiology and Pathology of Vegetables. J.A. Bartz and J.K. Brecht (Eds.). Marcel Dekker, New York.

9. Sargent, S.A., M.A. Ritenour, and J.K. Brecht. 2003. Handling, Cooling and Sanitation Techniques for Maintaining Postharvest Quality. Publ. HS719. In, The Vegetable Production Guide for Florida. S.M. Olson and E.H. Simonne (Eds.). Horticultural Sciences Department, Florida Cooperative Extension Service, University of Florida/IFAS, Gainesville. http://edis.ifas.ufl.edu/BODY_CV115.

10. Sherman, M. and D.D. Gull. 1981. A Flow-Through System for Introducing Ethylene in Tomato Ripening Rooms. Vegetable Crops Fact Sheet, VC-30, University of Florida/IFAS, Gainesville, FL 32611.
11. U.S.D.A. 1991. United States Standards for Grades of Fresh Tomatoes. U.S. Dept. Agric./AMS, Washington, DC. http://www.ams.usda.gov/standards/vegfm.htm.

12. U.S. Dept. of Health and Human Services. Center for Food Safety and Applied Nutrition. 1998. Guide to Minimize Microbial Food Safety Hazards for Fresh Fruits and Vegetables. Washington DC. http://www.foodsafety.gov/\%7Edms/prodguid.html

13. U.S.D.A. 2004. Vegetables. 2003 Summary. U.S. Dept. Agric. National Agr. Stat. Serv. Washington DC. Vg 1-2 (04). January. http://www.nass.usda.gov/fl/rtoc0ho.htm 
Table 1. Maturity ratings for green tomatoes sliced by a sharp knife through the equator (U.S. Dept. Agric., 1991).

\begin{tabular}{||c|l||}
\hline \hline Maturity Rating & Description \\
\hline M1 & Locule tissue solid; seeds are white and are sliced. \\
\hline M2 & One or two locules contain gel with tan seeds that do not slice. \\
\hline M3 & All locules contain gel with tan seeds that do not slice. \\
\hline M4 & Appearance of red coloration in locule tissue. \\
\hline \hline
\end{tabular}

Table 2. Color stage descriptions for ripening tomatoes (U.S.D.A., 1991).*

\begin{tabular}{||l|l||}
\hline \hline Ripeness Stage & External Appearance \\
\hline $1-$ Green & No external color change \\
\hline $2-$ Breaker & Not more than $10 \%$ color change \\
\hline $3-$ Turning & $\begin{array}{l}\text { More than } 10 \% \text {, but not more than } 30 \% \text { color } \\
\text { change }\end{array}$ \\
\hline $4-$ Pink & $\begin{array}{l}\text { More than } 30 \%, \text { but not more than to } 60 \% \text { color } \\
\text { change }\end{array}$ \\
\hline $5-$ Light Red & $\begin{array}{l}\text { More than } 60 \%, \text { but not more than to } 90 \% \text { color } \\
\text { change }\end{array}$ \\
\hline $6-$ Red & More than $90 \%$ color change \\
\hline $\begin{array}{l}{ }^{*} \text { For color plates see: } \\
\text { http://www.floridatomatoes.org/ }\end{array}$ & \\
\hline \hline
\end{tabular}

Table 3. Sizes and classifications for Florida tomatoes (Fla.

Tom. Comm. 2004).

\begin{tabular}{||l|l|l||}
\hline \hline Classification & Minimum (in) & Maximum (in) \\
\hline $6 \times 7$ & $29 / 32$ & $219 / 32$ \\
\hline $6 \times 6$ & $217 / 32$ & $229 / 32$ \\
\hline $5 \times 6$ \& Larger & $225 / 32$ & None \\
\hline \hline
\end{tabular}

